\title{
PENGARUH PERUBAHAN SPASIAL MIKROKLIMATIK AMONIA PADA ZONA PENEMPATAN DAN PANJANG KANDANG BERBEDA TERHADAP PERFORMA AYAM BROILER PERIODE STARTER
}

\section{The Effect of Changes in Spatial Amonia Microclimatics Due to Placement Zone and House Length Differences on Perfomance of Broiler Chicken at Starter Period}

Liza Meidzul Jannah, Teysar Adi Sarjana*, Edjeng Suprijatna

Laboratory of Poultry Production, Faculty of Animal and Agricultural Science, University of Diponegoro Jl. Prof. Soedarto, Tembalang, Semarang, Jawa Tengah, 50275

*E-mail: teysaradisarjana@ lecture.undip.ac.id

Submitted: July 11, $2019 \quad$ Accepted : March 27, 2020

\begin{abstract}
ABSTRAK
Penelitian ini bertujuan untuk mengkaji dampak perubahan spasial mikroklimatik amonia pada zona penempatan dan panjang kandang berbeda terhadap perfoma ayam broiler periode starter. Materi penelitian 2 unit closed house ukuran $60 \times 12 \mathrm{~m}^{2}$ berkapasitas 11.000 ekor dan ukuran $120 \times 12 \mathrm{~m}^{2}$ berkapasitas 22.000 ekor, 600 ekor DOC ayam broiler strain Cobb dalam rancangan perlakuan split plot acak kelompok dengan 2 mainplot, yaitu panjang kandang $60 \mathrm{~m}$ dan kandang $120 \mathrm{~m}$ dan 4 subplot, yaitu zona penempatan ayam terdiri dari Zona 1 (sejajar inlet), Zona 2 (1/4 panjang kandang), Zona 3 (1/2 panjang kandang) dan Zona 4 ( $3 / 4$ panjang kandang). Parameter yang diamati yaitu bobot badan, pertambahan bobot badan, konversi pakan, indeks perfoma, Income Over Feed Cost (IOFC), makroklimat dan mikroklimatik pada setiap unit zona penempatan ayam dan panjang kandang sebagai gambaran kondisi penelitian. Hasil penelitian menunjukkan terdapat interaksi antara zona penempatan ayam dan panjang kandang terhadap performa ayam broiler. Zona penempatan ayam yang lebih jauh dari inlet dan kandang yang lebih panjang menunjukkan hasil signifikan $(\mathrm{P}<0.05)$ menurunkan bobot badan, pertambahan bobot badan, indeks perfoma, dan IOFC, serta sebaliknya, meningkatkan konversi pakan. Simpulan penelitian ini adalah peningkatan spasial mikroklimatik amonia pada zona penempatan ayam yang lebih jauh dari inlet dan kandang yang lebih panjang menurunkan perfoma ayam broiler periode starter.
\end{abstract}

Kata kunci: Spasial mikroklimatik amonia, Zona penempatan, Panjang kandang, Perfoma, Ayam broiler

\section{ABSTRACT}

The research aimed to examine the effect of changes in spatial ammonia microclimatic due to zone placement and house length differences on the perfomance of broiler chicken at starter period. The material used were two units broilers closed house with different capacity, namely $60 \times 12 \mathrm{~m}^{2}$ with 11,000 chickens and $120 \times 12 \mathrm{~m}^{2}$ with 22,000 chickens, 600 DOC strain Cobb were allocated in a completely randomized block design of split-plot with two main plots, those were house length $60 \mathrm{~m}$ and $120 \mathrm{~m}$, and four subplot were placement zone of broiler chicken consists of Zone 1 (parallel to the inlet), Zone 2 (1/4 house length), Zone 3 (1/2 house length), Zone $4(3 / 4$ house length). The parameter observed were body weight, average daily gain, feed conversion ratio, index perfomance, Income Over Feed Cost (IOFC), macroclimate and microclimatic in each unit of chicken placement zone and house length differences as an illustration of the research condition. The results showed that there were interactions between the placement zone and house length on broiler performace. The further placement zone and the longer house distance from the inlet significantly $(\mathrm{P}<0.05)$ reduced the body weight, average daily gain, index perfomance and IOFC, while increased food conversion ratio. The conclusions of this study was the spatial microclimatic increase of ammonia in the placement zone of chickens which was farther from the inlet and the longes cages decreases the broiler performance at starter period.

Keywords: Spatial microclimatic ammonia, Placement zone, House length, Perfomance, Broiler chicken 


\section{PENDAHULUAN}

Indonesia merupakan negara tropis memiliki dua musim yaitu musim kemarau dan musim penghujan. Perbedaan antara dua musim tersebut berpengaruh terhadap pemeliharaan ayam broiler, antara lain perbedaan suhu, kelembaban, kecepatan angin dan radiasi matahari. Musim kemarau memiliki suhu yang cukup tinggi yaitu rata-rata $33^{\circ} \mathrm{C}$ (Qurniawan $e t$ al., 2016). Kondisi makroklimat musim kemarau tersebut berkontribusi terhadap kondisi mikroklimatik di dalam closed house, yaitu suplai udara masuk melalui inlet ke dalam kandang. Perubahan mikroklimatik amonia di dalam kandang berhubungan antara kelembaban dan $\mathrm{pH}$ litter di dalam kandang (Sarjana et al., 2017).

Amonia adalah gas yang dihasilkan dari dekomposisi limbah oleh bakteri nitrogen di dalam ekskreta yang tidak termetabolisme secara baik sehingga senyawa kompleks yang berasal dari limbah ekskreta mempengaruhi bau khas dari ammonia (Homidan et al., 2003). Spasial mikroklimatik amonia adalah perubahan mikroklimatik amonia akibat perbedaan jarak dari inlet dan volume ruang yang berbeda di dalam kandang berdasarkan adanya akumulatif antara suhu, kelembapan dan kecepatan angin. Distribusi penempatan populasi ayam di dalam closed house dibagi berdasarkan penempatan pen yang dipisahkan oleh jaring penyekat, pada penelitian ini disebut sebagai zona penempatan ayam. Posisi penempatan tersebut berimplikasi terhadap perubahan mikroklimatik di closed house seperti perubahan suhu, kelembaban, kecepatan angin dan heat index (Sarjana et al., 2017). Perbedaan penempatan tersebut berdasarkan jarak dari inlet juga berakibat pada perubahan akumulasi amonia meningkat (Renata et al., 2018). Amonia tinggi di dalam kandang dapat menyebabkan dampak negatif, yaitu penurunan perfoma, laju pertambahan dan peningkatkan konversi pakan serta penyakit pernafasan (Patterson dan Adrizal, 2005). Kadar amonia dapat ditolerir oleh unggas maksimal hingga 25 ppm (Homidan et al.,2003). Paparan mikroklimatik amonia secara langsung dapat menurunkan bobot badan hingga $8 \%$ pada ternak umur 0 - 4 minggu (Milles et al., 2004). Mikroklimatik amonia pada level $50-70 \mathrm{ppm}$, dapat menurunkan $6-9 \%$ bobot badan dan menurunkan $17-20 \%$ bobot badan ayam broiler pada minggu ke 7 (Baker et al., 2004).

Panjang closed house di Indonesia memiliki ukuran yang berbeda-beda sesuai dengan kapasitas ternak yang dipelihara, agar ternak nyaman dalam melakukan aktivitas dan cukup mendapatkan oksigen di dalam kandang
(Andisuro, 2011). Oksigen yang masuk ke dalam kadang berkurang pada kandang yang lebih panjang, karena kecepatan angin melambat dan populasi ayam semakin besar. Kandang dengan kepadatan ternak yang besar berdampak pada akumulasi pelepasan panas dan uap air ke lingkungan kandang dengan jumlah yang semakin banyak (Puspani et al., 2008). Perubahan kecepatan angin pada kandang yang lebih panjang berdampak pada peningkatan eliminasi mikroklimatik amonia dari inlet. Mikroklimatik amonia yang tinggi di dalam kandang mempengaruhi perfoma ayam broiler, karena mudah meningkatkan ternak terserang penyakit dan mortalitas (Milles et al., 2004).

Peningkatan spasial mikroklimatik amonia pada zona penempatan jauh dari inlet dan kandang lebih panjang diduga akan menurunkan perfoma ayam broiler periode starter. Penelitian ini bertujuan untuk mengkaji perubahan spasial mikroklimatik amonia pada zona penempatan dan panjang kandang closed house yang berbeda terhadap perfoma ayam broiler periode starter.

\section{MATERI DAN METODE}

\section{Materi}

Penelitian ini dilaksanakan di kandang closed house Fakultas Peternakan dan Pertanian Universitas Diponegoro Semarang pada periode bulan April - Mei 2019 di musim kemarau.

Materi penelitian adalah 2 unit closed house berukuran $60 \times 12 \mathrm{~m}^{2}$ dengan kapasitas 11.000 ekor dan $120 \times 12 \mathrm{~m}^{2}$ dengan kapasitas 22.000 ekor. Jumlah ayam sebanyak 600 ekor day old chicken (DOC) ayam broiler unsexed strain Cobb dengan bobot awal $\quad 46.76 \pm 2.83$ gram . Data diamati pada akhir periode starter saat umur 14 hari dengan manajemen pemeliharaan mengikuti standar pola usaha kemitraan yang diikuti oleh peternakan. Ransum selama periode starter terdiri dari 2 jenis yaitu S-10 untuk umur 1-10 hari dan S-11 untuk umur 10-20 hari. Kandungan nutrien ransum ayam yang digunakan selama penelitian disajikan pada Tabel 1.

\section{Metode}

Rancangan percobaan dalam pelaksanaan penelitian adalah rancangan perlakuan split plot dengan rancangan acak kelompok menggunakan 2 mainplot yang terdiri dari 2 kandang dengan ukuran 60 x $12 \mathrm{~m}$ dan $120 \times 12 \mathrm{~m}$, 4 subplot yang berupa zona penempatan ayam yaitu Zona $1=$ sejajar dengan inlet, Zona $2=1 / 4$ panjang kandang, Zona $3=1 / 2$ panjang kandang dan Zona $4=3 / 4$ panjang kandang dengan masing-masing 5 ulangan. 
Tabel 1. Hasil analisis proksimat jenis ransum yang digunakan selama penelitian. (Results of proximate analysis of ration types used during research)

\begin{tabular}{|c|c|c|c|c|c|c|c|}
\hline \multirow{2}{*}{$\begin{array}{c}\text { Jenis } \\
\text { ransum } \\
\text { (Type of } \\
\text { Ration) } \\
\end{array}$} & \multicolumn{7}{|c|}{$\begin{array}{c}\text { Kandungan Nutrien (\%) } \\
\text { (Nutrient Content, \%) }\end{array}$} \\
\hline & KA & PK & LK & SK & $\mathbf{C a}$ & Abu & EM* \\
\hline S-10 & 10.59 & 20.22 & 5.56 & 4.94 & 1.08 & 5.44 & 3155 \\
\hline S-11 & 10.79 & 19.31 & 6.04 & 6.32 & 1.16 & 5.39 & 3122 \\
\hline
\end{tabular}

Sumber : Hasil analisis proksimat. *Perhitungan berdasarkan Rumus Bolton (Sugiharto et al., 2017)

Tabel 2. Kondisi rata-rata Makroklimat dan Mikroklimat selama penelitian periode starter (Average conditions of Macroclimate and Microclimate during starter period research)

\begin{tabular}{|c|c|c|c|c|c|}
\hline $\begin{array}{c}\text { Makroklimat } \\
\text { (Macroclimate) }\end{array}$ & & \multicolumn{4}{|c|}{$\begin{array}{l}\text { Nilai } \\
\text { (Score) }\end{array}$} \\
\hline Suhu $\left({ }^{\circ} \mathrm{C}\right)$ & & \multicolumn{4}{|c|}{27.60} \\
\hline Kelembaban (\%) & & \multicolumn{4}{|c|}{79.40} \\
\hline Kecepatan angin $(\mathrm{Km} / \mathrm{jam})$ & & \multicolumn{4}{|c|}{1.50} \\
\hline Radiasi matahari $\left(\mathrm{W} / \mathrm{m}^{2}\right)$ & & \multicolumn{4}{|c|}{267.70} \\
\hline Mikroklimat & $\begin{array}{l}\text { Panjang } \\
\text { Kandang }\end{array}$ & Zona 1 & Zona 2 & Zona 3 & Zona 4 \\
\hline \multirow[t]{2}{*}{ Suhu $\left({ }^{\circ} \mathrm{C}\right)$} & $60 \mathrm{~m}$ & 30.46 & 31.03 & 31.03 & 31.60 \\
\hline & $120 \mathrm{~m}$ & 29.19 & 30.13 & 30.55 & 31.11 \\
\hline \multirow[t]{2}{*}{ Kelembaban (\%) } & $60 \mathrm{~m}$ & 79.54 & 79.71 & 80.05 & 79.94 \\
\hline & $120 \mathrm{~m}$ & 82.50 & 83.52 & 81.91 & 80.97 \\
\hline \multirow[t]{2}{*}{ Kecepatan Angin (Km/jam) } & $60 \mathrm{~m}$ & 1.08 & 0.87 & 0.81 & 0.65 \\
\hline & $120 \mathrm{~m}$ & 1.13 & 0.68 & 0.91 & 1.12 \\
\hline \multirow[t]{2}{*}{ Spasial mikroklimatik amonia (ppm) } & $60 \mathrm{~m}$ & 0.53 & 0.87 & 1.16 & 1.46 \\
\hline & $120 \mathrm{~m}$ & 0.74 & 0.95 & 1.19 & 1.87 \\
\hline
\end{tabular}

Keterangan : Data penelitian

\section{Parameter}

Parameter yang diamati untuk menggambarkan capaian perfoma ayam broiler terdiri dari bobot badan, pertambahan bobot badan (PBB), konversi pakan, indeks perfoma (IP) dan Income Over Feed Cost (IOFC). Perhitungan IOFC dikalkulasi berdasarkan harga ransum starter Rp 7.575,00/kg dan harga bobot hidup $\mathrm{Rp} \quad 17.500,00 / \mathrm{kg}$. Rata-rata kondisi makroklimat dan mikroklimat juga diamati untuk memberikan gambaran kondisi penelitian. Pengambilan data rata-rata tersebut dilakukan pukul 05.00, 13.00 dan 21.00 WIB yang disajikan pada Tabel 2. Data yang diperoleh di analisis ragam dan selanjutnya data yang menunjukkan dampak pengaruh nyata $(\mathrm{P}<0,05)$ di uji Duncan.

\section{HASIL DAN PEMBAHASAN}

Hasil analisis ragam menunjukkan bahwa terdapat interaksi signifikan antara zona penempatan ayam dan panjang kandang terhadap bobot badan, pertambahan bobot badan, konversi pakan, indeks perfoma dan IOFC ayam broiler periode starter sebagaimana disajikan pada Tabel 3. Zona penempatan ayam semakin jauh dari inlet dan kandang lebih panjang menurunkan perfoma ayam broiler periode starter.

\section{Bobot Badan}

Kandang 120 meter dan zona penempatan ayam lebih jauh dari inlet, bobot badan ayam broiler lebih rendah dibanding dengan kandang 60 meter pada zona lebih dekat dari inlet. Bobot badan pada kandang $60 \mathrm{~m}$ signifikan lebih rendah mulai terjadi pada penempatan ayam zona 3 , sedangkan pada kandang $120 \mathrm{~m}$ capaian bobot badan lebih rendah terjadi mulai pada penempatan ayam zona 1. Capaian bobot badan ayam broiler yang lebih rendah pada panjang kandang maupun zona penempatan yang terjadi diduga akibat peningkatan akumulasi spasial mikroklimatik amonia di dalam kandang yang lebih panjang dan zona penempatan ayam lebih jauh dari inlet. Bobot badan lebih rendah pada zona lebih jauh dari inlet dan kandang $120 \mathrm{~m}$ diduga disebabkan 2 hal yaitu (1) stres oksidatif karena iritasi saluran pernafasan yang menyebabkan ternak tidak mampu mengambil oksigen secara maksimal sehingga mengakibatkan laju metabolisme terganggu dan deposisi protein menurun; (2) peningkatan heat stress pada kandang yang 
lebih panjang dan zona penempatan ayam lebih jauh dari inlet.

Spasial mikroklimatik ammonia pada zona penempatan sejajar dengan inlet pada kandang $60 \mathrm{~m}$ adalah $0,53 \mathrm{ppm}$ dan meningkat menjadi 1,16 ppm pada penempatan ayam di zona 3, sedangkan pada kandang $120 \mathrm{~m}$ spasial mikroklimatik ammonia di zona penempatan sejajar dengan inlet adalah $0,74 \mathrm{ppm}$ dan meningkat menjadi 1,19 ppm pada penempatan ayam zona 3 sehingga mengakibatkan terjadinya stres oksidatif yang dipelihara pada zona penempatan ayam lebih jauh dari inlet dalam hal ini pada zona 3. Hal ini sesuai dengan pendapat Subkhie et al. (2012) dan Milles et al. (2004) menyatakan bahwa mikroklimatik amonia pada level 50 - 70 ppm dapat menurunkan capaian bobot badan hingga $17-21 \%$ pada ayam broiler umur 0 - 4 minggu, apabila ayam broiler terkena paparan mikroklimatik ammonia secara langsung dan terus-menerus akan berdampak kerusakan saluran pernafasan sehingga efisiensi ransum rendah dan meningkatkan kerentanan ternak terhadap penyakit pernafasan.
Bobot badan yang lebih rendah pada kandang yang lebih panjang dan zona penempatan ayam lebih jauh dari inlet diduga terjadi akibat peningkatan spasial mikroklimatik amonia di dalam kandang yang berdampak terjadinya heat stres. Potensi heat stres diduga terjadi akibat inefisiensi heat loss karena unggas tidak dapat membuang panas secara maksimal diikuti dengan penekanan konsumsi ransum untuk mengurangi produksi panas. Hal ini sesuai dengan hasil penelitian Tamzil (2014) bahwa peningkatan amonia dapat mengganggu ternak dalam pelepasan panas sehingga mengakibatkan penurunan efisiensi panting, peningkatan konsumsi minum dan penurunan konsumsi ransum. Pada penelitian lain, Sugito et al. (2010) menyatakan bahwa cekaman panas berdampak pada pertumbuhan ayam broiler yang terhambat, karena penggunaan energi lebih banyak digunakan untuk homeostasis dibandingkan untuk pertumbuhan.

Tabel 3. Hasil Analisis Ragam bobot badan, pertambahan bobot badan, konversi pakan, indeks perfoma dan IOFC

(Results of the analysis of body weight, increase in body weight, feed conversion, performance index and IOFC)

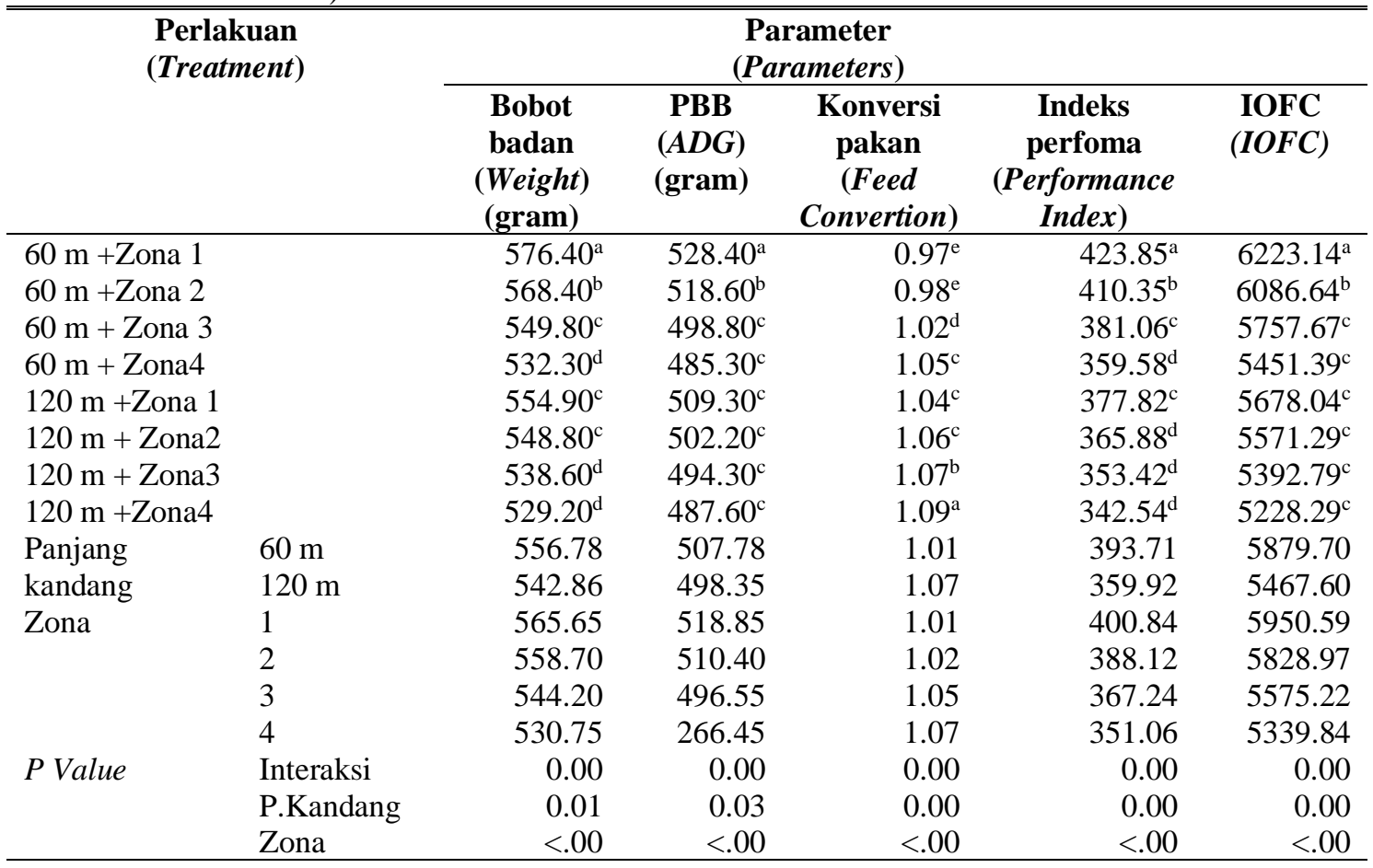

Keterangan: Superskrip berbeda pada nilai rata-rata di kolom yang sama menunjukkan perbedaan nyata $(\mathrm{P}<0,05)$. 


\section{Pertambahan Bobot Badan dan Konversi Pakan}

Zona penempatan ayam yang lebih jauh dari inlet dan kandang yang lebih panjang menunjukkan pertambahan bobot badan yang lebih rendah dan koversi pakan yang lebih tinggi. Pertambahan bobot badan yang lebih rendah dan konversi pakan yang lebih tinggi pada kandang $60 \mathrm{~m}$ terjadi pada penempatan ayam zona 3, sedangkan pada kandang $120 \mathrm{~m}$ pertambahan bobot badannya setara dengan kandang $60 \mathrm{~m}$ pada penempatan ayam zona 3. Konversi pakan kandang $120 \mathrm{~m}$ mulai meningkat pada penempatan ayam zona 3. Pertambahan bobot badan lebih rendah dan konversi pakan lebih tinggi diduga karena adanya peningkatan akumulasi spasial mikroklimatik amonia pada kandang yang lebih panjang dan zona penempatan ayam jauh dari inlet. Peningkatan tersebut mengakibatkan iritasi pada saluran pernafasan sehingga uptake oksigen yang masuk kedalam tubuh tidak maksimal mengakibatkan laju metabolisme di dalam tubuh terganggu yang berakibat pada pertambahan bobot badan melambat dan konversi pakan meningkat. Hasil penelitian ini konsisten dengan penelitian Wideman et al. (2013) bahwa pencapaian pertambahan bobot badan lebih rendah dan konversi pakan lebih tinggi disebabkan oleh kerusakan pada organ paru-paru yang berasal dari dampak meningkatnya amonia di dalam kadang dan stres oksidatif. Peningkatan stres oksidatif dapat menyebakan ternak mudah terserang penyakit pernafasan dan meningkatkan mortalitas (Milles et al., 2004).

Capaian pertambahan bobot badan lebih rendah dan konversi pakan lebih tinggi pada zona penempatan lebih jauh dari inlet dan kandang lebih panjang diduga juga terjadi akibat ketersedian oksigen pada zona penempatan ayam yang lebih jauh dari inlet dan kandang lebih panjang berkurang disebabkan oleh peningkatan akumulasi spasial mikroklimatik amonia pada zona penempatan ayam lebih jauh dari inlet dan kandang lebih panjang. Ketersedian oksigen berkurang diakibatkan akumulasi pemanfaatan pada zona sebelumnya dan mekanisme reaksi pembentukan amonia membutuhkan oksigen dan menghasilkan karbondioksida. Kondisi tersebut meningkatkan karbondioksida sehingga berpotensi menurunkan laju metabolisme ayam broiler mengakibatkan pertambahan bobot badan melambat dan konversi pakan menurun. Hal ini sesuai dengan pendapat Petterson dan Adrizal (2005) bahwa pembentukan amonia membutuhkan ketersedian oksigen $\mathrm{C}_{5} \mathrm{H}_{4} \mathrm{O}_{3} \mathrm{~N}_{4}+1,5 \mathrm{O}_{2}+4 \mathrm{H}_{2} \mathrm{O} \rightarrow 4 \mathrm{NH}_{3}+5 \mathrm{CO}_{2}$, berdasarkan persamaan tersebut untuk setiap pembentukan 4 molekul $\mathrm{H}_{2} \mathrm{O}$ dan 1,5 molekul oksigen, serta 1 molekul $\mathrm{C}_{5} \mathrm{H}_{4} \mathrm{O}_{3} \mathrm{~N}_{4}$, menghasilkan 5 molekul karbondioksida dan 4 molekul amonia. Rendahnya pertambahan bobot badan dan tingginya konversi pakan pada zona penempatan ayam lebih jauh dari inlet dan kandang lebih panjang diduga juga terjadi akibat peningkatan spasial mikroklimatik amonia di dalam kandang. Peningkatan tersebut mengakibatkan terjadinya heat stress diduga akibat inefisiensi heat loss yang disebabkan oleh iritasi saluran pernafasan, berdampak meningkatkan suhu tubuh ayam broiler. Peningkatan suhu tubuh tersebut juga mengakibatkan penurunan hormon T3 (triiodothyronin) yang merupakan hormon pertumbuhan. Menurut Kusnadi dan Rahim (2009) menyatakan penurunan hormon T3 terjadi karena peningkatan suhu tubuh yang berdampak pada mekanisme kinerja hormonal laju pertambahan juga menyebabkan penurunan deposisi protein karena terjadi penurunan efisiensi ransum sehingga pertambahan bobot badan lebih rendah dan konversi pakan lebih tinggi pada zona yang lebih jauh dari inlet dan kandang lebih panjang. Hal ini sesuai dengan pendapat Decuypere et al. (1987) bahwa T3 yang disirkulasikan berkolerasi positif dengan konsumsi ransum dan berkorelasi negatif dengan suhu. Pada penelitian ini, penurunan konsumsi ransum sudah mulai terjadi pada zona penempatan ayam di zona 3 dengan kadar ammonia pada kandang $60 \mathrm{~m}$ sebesar 1,16 ppm dan pada kandang $120 \mathrm{~m}$ sebesar 1,19 ppm.

\section{Indeks Perfoma dan Income Over Feed Cost}

Kandang $120 \mathrm{~m}$ dan zona penempatan ayam yang lebih jauh dari inlet menunjukkan capaian nilai Indeks Perfoma (IP) dan Income Over Feed Cost (IOFC) yang lebih rendah dibanding dengan kandang $60 \mathrm{~m}$ dan zona penempatan ayam yang dekat dari inlet. Nilai IP dan IOFC yang lebih rendah pada kandang $60 \mathrm{~m}$ terjadi pada penempatan ayam zona 3 , namun pada kandang $120 \mathrm{~m}$ nilai IP lebih rendah pada penempatan ayam zona 2 , sedangkan nilai IOFC pada kandang $120 \mathrm{~m}$ setara dengan nilai IOFC pada kandang $60 \mathrm{~m}$ di penempatan ayam pada zona 3. Hal ini sesuai dengan penelitian Arifudin et al. (2018) yang menyatakan bahwa nilai IP ayam broiler yang dipelihara pada kandang closed house pada zona penempatan yang lebih jauh dari inlet menunjukkan capaian yang lebih rendah dibandingkan dengan zona penempatan ayam yang dekat dengan inlet, namun berdasarkan hasil analisis ragam, nilai IP pada penelitian ini lebih tinggi dibandingkan dengan standar kemitraan 
closed house pada umur yang sama, yaitu sebesar 305.

Capain nilai IP dan IOFC pada zona penempatan ayam lebih jauh dari inlet dan kandang lebih panjang menunjukkan hasil lebih rendah dibandingkan pada zona penempatan ayam yang lebih dekat dari inlet dan kandang lebih pendek, hal ini diduga terjadi akibat peningkatan akumulasi spasial mikroklimatik amonia pada zona penempatan lebih jauh dari inlet dan kandang lebih panjang berpengaruh terhadap laju pertumbuhan bobot badan ayam broiler, sehingga mengakibatkan bobot badan rendah dan konversi pakan buruk, serta tingkat kematian tinggi. Hal ini sesuai pendapat Moore et al. (1996) yang menunjukkan bahwa peningkatan kadar amonia pada level 25 - 85 ppm menyebabkan konversi pakan rendah sehingga keuntungan yang diperoleh menjadi lebih rendah.

\section{SIMPULAN}

Peningkatan spasial mikroklimatik amonia pada zona penempatan ayam lebih jauh dari inlet dan kandang lebih panjang menurunkan perfoma ayam broiler periode starter.

\section{DAFTAR PUSTAKA}

Andisuro, R. 2011. Tingkah Laku Ayam Broiler di Kandang Tertutup Dengan Suhu dan Warna Cahaya Berbeda. Institut Pertanian Bogor. Bogor.

Arifudin, K., T.A. Sarjana., R. Muryanu., L. D. Mahfudz., D. Sunarti., W. Sarengat and I.P. Angkeke. 2018. Zonation in closed house effecting ammonia emission, immune system and broiler perfomace in the dry. Prosiding International Conference of Animal Science and Technology. 24 July 2019. Makasar, Indonesia.

Beker, A., S. L. Vanhooser., J. H. Swartzlander and R. G. Teeter. 2004. Atmospheric Ammonia concentration effect on broiler growth and perfomace. Poultry Sci. J. 13: $5-9$.

Decuypere. E., Buyse.J., Scanes. C.G., Huybrecht.L and Kuhn E.R. 1987. Effects of hyper- or hypothyroid status on growth, adiposity and levels of growth hormone, somatomedin $\mathrm{C}$ and thyroid metabolism in broiler chickens. Reprod Nutr. Dev. 27 (2B): 555-565

Homidan, A. A., J. F. Robertson dan A. M. Petchey. 2003. Review of the effect of ammonia dust concentrations on broiler perfomace. Poultry Sci. J. 59 : 340 - 349.

Kusnadi, E dan F. Rahim. 2009. Performa dan kandungan triiiodotironin plasma ayam broiler akibat pengaruh cekaman panas didaerah tropis. Med. Pet. 32(3): 155-162.

Milles, D. M. S. L. Branton and B. D. Lott. 2004. Atmospheric ammonia is detrimental to perfomace of modern commercial broiler. Poultry Sci. J. 83: 1650-1654.

Moore, P. A., T. C. Daniel ., D. R. Edwars and D. M. Miller. 1995. Evaluation of chemical amendments to reduce ammonia volatilization from poultry litter. Poultry Sci. J. : 75: 315-320.

Patterson, P.H dan Adrizal. 2005. Management strategies to reduce air emission: emphasis-dust and ammonia. Applied Poultry Research 14(3): 638-650.

Puspani, E., I. M. Nuriyasa dan A. P. Wibawa. 2008. Pengaruh tipe lantai kandang dan ternak terhadap tabiat makan ayam pedaging umur 2 - 6 minggu. Majalah Ilmiah Peternakan 32(3):155.

Qurniawan, A., I. I. Arief dan R. Afnan. 2016. Perfoma produksi ayam pedaging pada lingkungan pemeliharaan dengan ketinggian yang berbeda di Sulawesi Selatan. J. Veteriner: 17 (4): 622-633.

Renata., T. A. Sarjana dan S. Kismiati. 2018. Pengaruh zonasi dalam kandang closed house terhadap kadar amonia dan dampaknya pada kualitas daging broiler di musim penghujan. J. Ilmu-Ilmu Peternakan 28 (3): 183-191.

Sarjana, T. A., L. D. Mahfudz, M. Ramadhan, Sugiharto, F. Wahyono, and S. Sumarsih. 2017. Ammonia emission and litter condition of broiler reared in conventional open housing system feed different additive inclusion and its combination in ration. Prosiding seminar Nasional Pengembangan Peternakan Berkelanjutan 9. 15 November 2017. Sumedang, Indonesia.

Sugito., R. Erdiansah., Azhari dan M. Isa. 2010. Pertambahan bobot badan dan waktu pembusukan daging ayam broiler yang diekstrak jaloh dikombinasi dengan kromium. Agripet. 10(2): 21-26.

Subkhie, H., Suryadi dan S. Amiruddin. 2012. Analisis kelayakan usaha peternakan ayam broiler pedaging dengan pola kemitraan di kecamatan Ciampea Kabupaten Bogor. $J$. Manajemen IKM 7(1): 54-63.

Sugiharto, S., T. Yudiarti and I.Isroli. 2017. Effect of feeding cassava puip fermented with 
acremonium charticola on growtth perfomace, nutrient digestibility and meat quality of broiler chicks. J. Anim. Sci. South African 47(2): 130-138.

Tamzil., M. H. 2014. Stres panas pada unggas: Metabolisme, akibat dan upaya penanggulangannya. Wartazoa 24(2): 57 66

Wideman, R.F, D.D Rhoads, G.F Erf and N.B Anthony. 2013. Pulmonary arterial hypertension (ascites syndrome) in broilers: A review. Poultry Sci. J. 92 : 6483. 